\title{
AMOC modes linked with distinct North Atlantic deep water formation sites
}

\author{
Mihai Dima ${ }^{1,2}$ (D) Gerrit Lohmann ${ }^{1} \cdot$ Monica Ionita ${ }^{1,3} \cdot$ Gregor Knorr $^{1} \cdot$ Patrick Scholz $^{1}$
}

Received: 17 May 2021 / Accepted: 14 January 2022 / Published online: 31 January 2022

(c) The Author(s) 2022

\begin{abstract}
The Atlantic Meridional Overturning Circulation (AMOC) is a tipping component of the climate system, with a quasi-global impact. Several numerical and observational studies emphasized two modes of AMOC variability, characterized by two distinct Atlantic sea surface temperature patterns. One is associated with centennial changes, the Trend Mode, and the other with the Atlantic Multidecadal Oscillation (AMO). The origin of the different manifestations of these modes it is not fully understood. Using observational data and an ocean general circulation model we present evidence that, whereas the Trend Mode is mainly linked with deep water formation in the Nordic Seas and with a North Atlantic AMOC cell centered at $50^{\circ}$ $\mathrm{N}, \mathrm{AMO}$ is related with deep water formation in the Labrador and Irminger Seas and with an overturning cell centered at $20^{\circ}$ $\mathrm{N}$. In combination with previous studies, these results imply that a main route of increasing atmospheric $\mathrm{CO}_{2}$ concentration influence on AMOC passes through deep water formation in the Nordic Seas and it is reflected in a subpolar North Atlantic meridional cell.
\end{abstract}

Keywords Atlantic Meridional Overturning Circulation · Deep water formation sites · Climate modes

\section{Introduction}

The Atlantic Meridional Overturning Circulation (AMOC) is one of the major tipping elements of the climate system (Buckley and Marshall 2016; Lenton et al. 2008). It has a nonlinear behavior linked to thresholds (Stommel 1961; Rahmstorf 1995) and played a key role in past major climate changes (e.g. Knorr and Lohmann 2007). AMOC has a large impact (e.g. Vellinga and Wood 2008; Liu et al. 2017), enhanced by its links with the Atlantic sea surface temperature (SST), which spreads its influence across the globe, through atmospheric teleconnections (e.g. Li et al. 2014). Through its transport of heat and carbon from the surface to the deep levels, it plays a major role in the climate response

Mihai Dima

mihai.dima@unibuc.ro

1 Alfred Wegener Institute for Polar and Marine Research, Bremerhaven, Germany

2 Faculty of Physics, University of Bucharest, București, Romania

3 Emil Racoviță Institute of Speology, Romanian Academy, 400006 Cluj-Napoca, Romania to anthropogenic forcing (Drijfhout et al. 2012; Marshall et al. 2014).

Whereas on intra-annual and interannual timescales AMOC variability is driven by local wind forcing, on decadal and longer timescales thermohaline processes become an important control factor. Decadal and centennial Atlantic overturning variations are thought to originate from subpolar regions, in response to time varying deep water formation (Zhang 2010) and buoyancy forcing (Yeager and Danabasoglu 2014). These processes manifest in localized regions with deep convective mixing, like the Labrador and Irminger Sea (Labrador Irminger Seas Deep Water Formation-LISDWF) (Jungclaus et al. 2005; Kuhlbrodt et al. 2007) and the Nordic Seas (Nordic Seas Deep Water FormationNSDWF) (Langehaug et al. 2012). Overflow Waters formed via NSDWF and delivered to the North Atlantic across the Greenland-Iceland-Scotland Ridge are denser than Labrador Sea water. Disruptions of deep convection in these regions can induce large changes of the Atlantic overturning (Zhang and Delworth 2005; Zhang et al. 2011).

For the historical period models simulate a modest AMOC decrease between preindustrial (1850-1900) and present day (2006-2015), which is most pronounced during the last decades (Collins et al. 2019). Most climate 
projections indicate that it will suffer a centennial scale slowdown during the twenty-first century, mainly in response to intensified North Atlantic freshwater and heat fluxes, induced by increased atmospheric $\mathrm{CO}_{2}$ concentration (Collins et al. 2013). This is supported by analyses based on observational data (Dima et al. 2021). However, there are significant quantitative differences between the various model simulations, which imply large uncertainties regarding the future evolution of the Atlantic overturning.

Observations about this oceanic component are necessary in order to constrain its variability. Direct measurements of AMOC intensity extend over a relatively short period of time (Bryden et al. 2005; Smeed et al. 2014; Srokosz and Bryden 2015), but they are complemented by indirect inferences based on long-term observational SST fields or subsurface information (Latif et al. 2004, 2006; Lohmann et al. 2008; Zhang et al. 2019). Indirect observational evidence indicates that the AMOC weakening trend already started in the late-nineteenth century and that its low-level intensity during the last decades is unprecedented in the last millennium (Rahmstorf et al. 2015; Caesar et al. 2021).

While the understanding of the AMOC dynamics requires breaking down Atlantic Ocean circulation into its unintegrated components (Wunsch and Heimbach 2013), an approach towards reducing the uncertainty about its evolution could be based on a decomposition of its variations. Historical simulations from the Coupled Model Intercomparation Project Phase 5 show that the first two dominant modes of AMOC changes, explaning $71 \%$ of the total variance, are represented by a centennial and an oscillatory multidecadal component (Cheng et al. 2013). Consistent with these, two AMOC modes were presented in a multi-millennial control integration of the Kiel Climate Model (Park and Latif 2008), together with their distinct projections on the SST field. These two modes, a centennial trend and the Atlantic Multidecadal Oscillation (AMO), were also separated based on instrumental SST fields (Dima and Lohmann 2010). It was shown that they explain the largest part of variance at multidecadal and longer time scales variance for an SSTbased AMOC index (Dima et al. 2021). Numerical simulations show that North Atlantic SST indices reproduce, with significant accuracy, the decadal to centennial AMOC variations (Latif et al. 2004; Rahmstorf et al. 2015; Caesar et al. 2018).

The goal of this study is to identify the origin of the different manifestations of these two AMOC modes. Our strategy consists in: (1) separation of the two observed Atlantic SST footprints, which were linked to overturning changes in previous studies; (2) identification of the two Atlantic SST footprints in fields derived from a simulation with an ocean general circulation model; (3) identification of the AMOC modes associated with the Atlantic SST footprints in simulated fields; (4) investigation of the potential connections between
AMOC/SST modes and the North Atlantic deep water formation regions.

\section{Data and methods}

As the AMOC transports a large amount of heat, one could infer ocean circulation changes based on observed SST data, the longest measured oceanic quantity. As we investigate interannual to centennial variability and one needs accurately determined spatial patterns, we use the HadISST.v1.1 data set distributed on a global grid with a $1^{\circ} \times 1^{\circ}$ spatial resolution and which covers the $1870-2016$ period (Rayner et al. 2003).

The Empirical Orthogonal Functions (EOF) method is used in order to separate observed SST modes. Before applying this method, the global warming trend is removed by subtracting the annual global mean from each grid point. The global mean time series is quasi-identical with that of the average SST anomalies over a smaller domain (e.g. $0-360^{\circ} \mathrm{E}, 70^{\circ} \mathrm{S}-70^{\circ} \mathrm{N}$ ) and therefore the subtracting method is not sensitive to scarcity of data in high latitudes. EOF is applied to annual mean anomalous SST fields, covering the Atlantic basin $\left(75^{\circ} \mathrm{W}-20^{\circ} \mathrm{E}, 80^{\circ} \mathrm{S}-80^{\circ} \mathrm{N}\right)$. In order to check the robustness of the results across datasets, the analyses were performed also based on the ERSST.v5 data set, distributed on a global grid with a $2^{\circ} \times 2^{\circ}$ resolution, covering the 1854-2016 period (Huang et al. 2015), with virtually identical results (not shown).

EOF analyses are also performed on SST, meridional overturning stream function and mixed layer depth (MLD) fields derived through a simulation performed with an ocean general circulation model. The Finite-Element SeaIce Ocean Model (FESOM) is integrated in a regionally focused, but globally covered model setup. The model has a regional resolution of up to $7 \mathrm{~km}$, and the simulations cover the 1958-2009 time period (Scholz et al. 2013, 2014). The model set-up was designed to study the variability in the deep-water formation areas and was therefore regionally better resolved in the Labrador Sea, Greenland Sea, Weddell Sea and Ross Sea. The ocean state of the model set-up features pronounced variability in the Atlantic Meridional Overturning Circulation as well as the associated mixed layer depth pattern in the North Atlantic deep-water formation areas (Scholz et al. 2013, 2014; Ionita et al. 2016).

\section{Results}

\subsection{Two distinct observed SST modes}

The first EOF of the observed Atlantic SST field, explaining $21 \%$ of the total variance, is marked by significant loadings located in regions with vertical components of the ocean 
circulation, like the subpolar gyre and the Gulf Stream, but also in the Gulf of Guinea and the mid-latitudes of the South Atlantic, indicating a direct link with fluctuations in the deep ocean levels (Fig. 1c). It includes also an inter-hemispheric dipole, indicative of AMOC fluctuations. The corresponding time component is characterized by a centennial-scale trend (Fig. 1a). The Trend Mode (hereafter TM) pattern is marked by three centers of alternating signs, disposed from SW to SE of Greenland (Fig. 1c), a structure which was linked to overturning changes (Born et al. 2009; Zhang et al. 2011; Drijfhout et al. 2012).

One notes that the North Atlantic structure of EOF1 has some projection on the tripole pattern, which was linked with the North Atlantic Oscillation (NAO) impact on the SST fields (Viesbeck et al. 2003). However, whereas NAO is dominated by interannual variability and show no centennial scale trend, $\mathrm{PC} 1$ is marked by a long term increase starting in the late nineteenth century (Fig. 1a), which is of specific importance here. The NAO impact on the SST field appears to be rather reflected in EOF4 and EOF5 of the Atlantic SST field, which resemble the tripole pattern in North Atlantic (Fig. S2).

Both, EOF2 and EOF3 show dominant positive anomalies in North Atlantic and include also anomalies of opposite sign in the Southern Hemisphere sector of this basin (Fig. S1). Furthermore, their time components are marked by multidecadal fluctuations. As these features are characteristics of AMO's footprint on the SST field, we consider that these two EOFs/PCs, together, describe this mode. Its spatial structure is obtained by adding their patterns (previously multiplied by the standard deviations of the corresponding PCs) and its time component is derived by adding the associated PCs. This mode explains 19\% of variance (obtained as the sum of the variances explained by EOF2 and EOF3). The north-south dipolar structure is the typical surface footprint of AMOC variations (Latif et al. 2004; Marini and Frankignoul 2014). As its structure includes positive anomalies distributed over almost the whole North Atlantic, it likely reflects intensified northward heat transport due to strong AMOC (Latif et al. 2004). The resulted time series includes the typical time intervals of positive and negative AMO phases (Sutton and Hudson 2005; Dima and Lohmann 2007) and it is characterized by the abrupt transitions between two distinct states (Dima and Lohmann 2011) (Fig. 1b). These properties represent the typical spatial and temporal characteristics of the AMO (Schlesinger and Ramankutty 1994). Several studies indicate that this mode is linked with AMOC changes (Latif et al. 2004; Knight et al. 2005). Here we further investigate these proposed links.

We consider the identification of the modes through this procedure as optimal, based on three criteria:
1. A very similar decomposition of AMOC long-term variability over the instrumental period in two modes was emphasized based on control and historical model integrations (Schmidt et al. 2014) and based only on North Atlantic SSTs (Dima et al. 2021);

2. The two reconstructed modes have clear distinct characteristics, without containing mixed information, as do the initial EOFs/PCs. Whereas, AMO is characterized by multidecadal fluctuations and a monopolar spatial structure in North Atlantic, the Trend Mode is associated with a centennial trend and a tripolar structure in this sector; the correlation between the corresponding reconstructed time components is insignificant;

3. The sum of the time components of these two distinct modes reconstructed based on the North Atlantic SSTs is significantly correlated (0.77) with an SST-based AMOC index (Dima et al. 2021; Fig. 1e in their study), suggesting that together, these two modes provide a quasi-complete decomposition of AMOC decadal and longer-term variability.

The existence of two distinct AMOC modes, with different projections on the Atlantic SST, raises the question: what is the origin of the differences between the manifestations of these two types of variations? In order to address this question, we analyze oceanic fields derived from an ocean general circulation model integration.

\subsection{Two simulated SST modes}

An EOF analysis was also performed on the annual Atlantic $\left(75^{\circ} \mathrm{W}-20^{\circ} \mathrm{E}, 80^{\circ} \mathrm{S}-80^{\circ} \mathrm{N}\right) \mathrm{SST}$ field simulated with the FESOM model (Scholz et al. 2013, 2014). In the simulation, the second Atlantic SST-EOF, explaining 13\% of variance includes the three centers of alternating signs extending from the Gulf Stream area to the Nordic Seas (Fig. 2a), which are typical for the AMOC trend mode (Fig. 1c). The associated time series is dominated by a growing trend and aligns well with the corresponding observed component (Fig. 1a). The correlation coefficient over the common period is 0.58 .

The dominant EOF of the simulated SST field, explaining $19 \%$ of total variance, is marked by the AMO typical interhemispheric dipole (Fig. 2b). The associated time component, which is well aligned with the corresponding observed time series (Fig. 1b), reflects the AMO positive phases (1958-1968 and 1997-2009) and its negative state extending over 1970-1990 time interval. The correlation coefficient over the common period is 0.69 . The similarity between the two pairs of patterns and time components indicates that FESOM simulates well the two SST modes. 

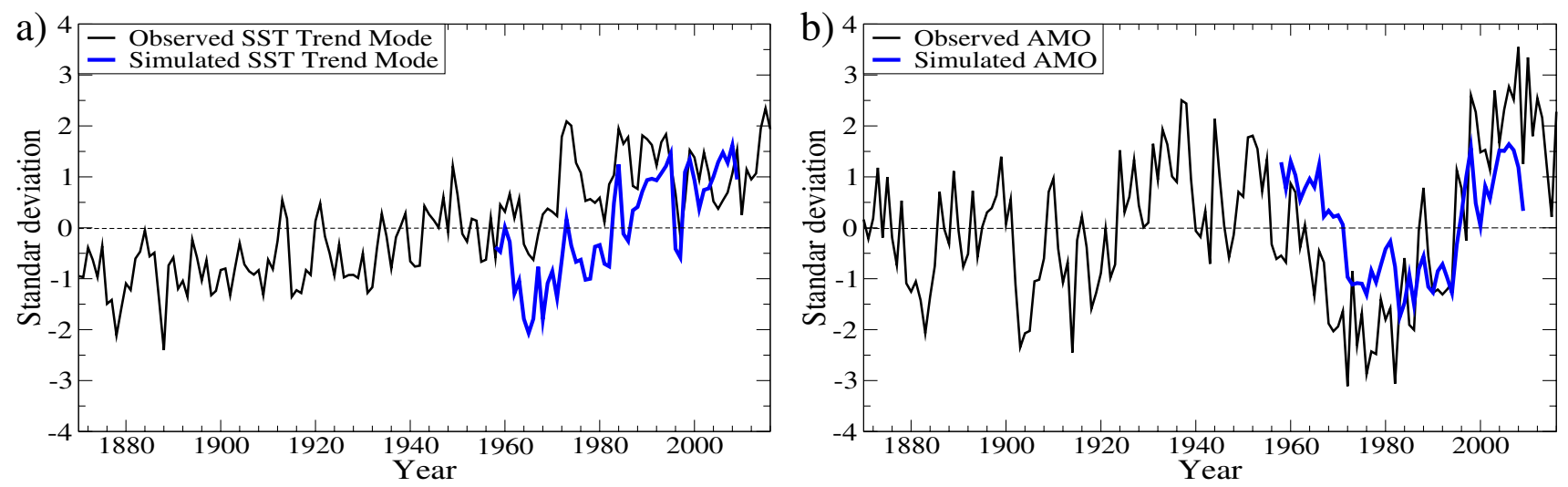

\section{c) Observed Trend Mode}

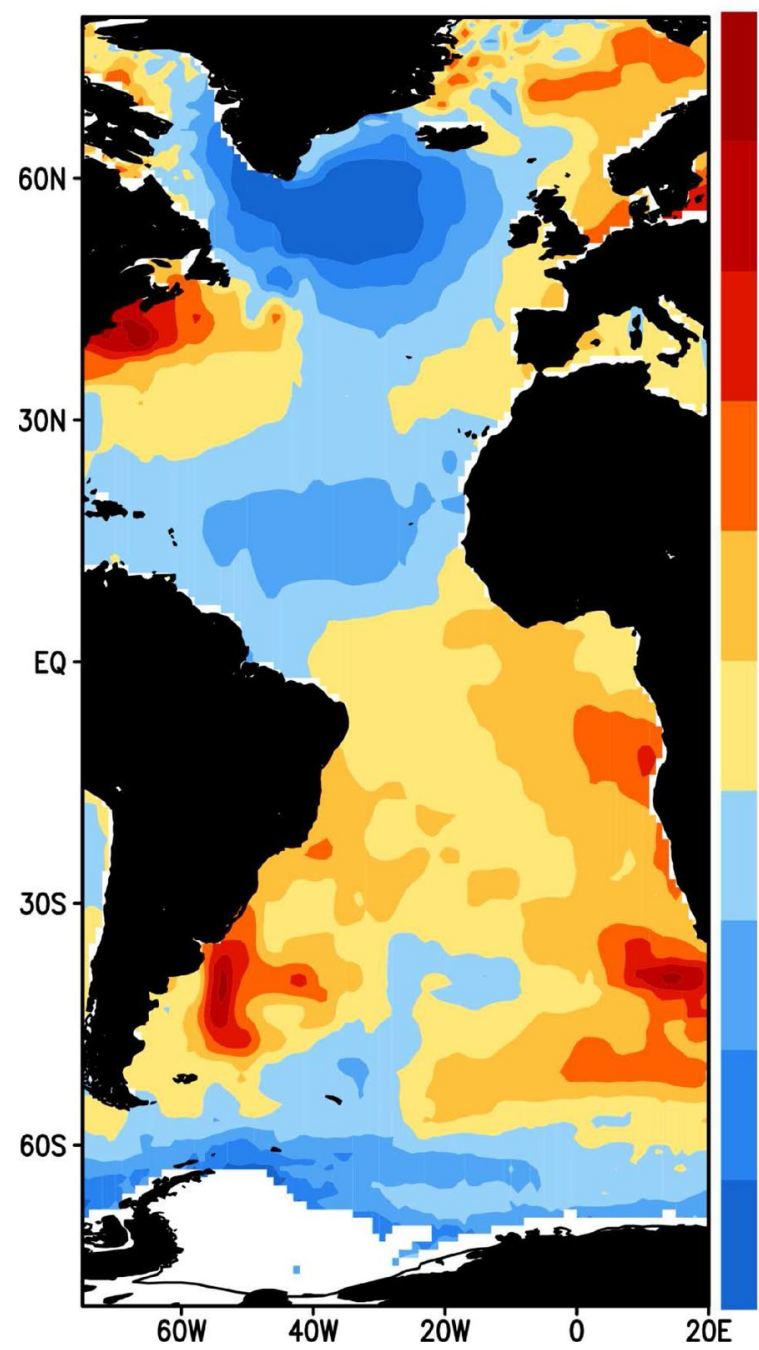

d)

Observed AMO

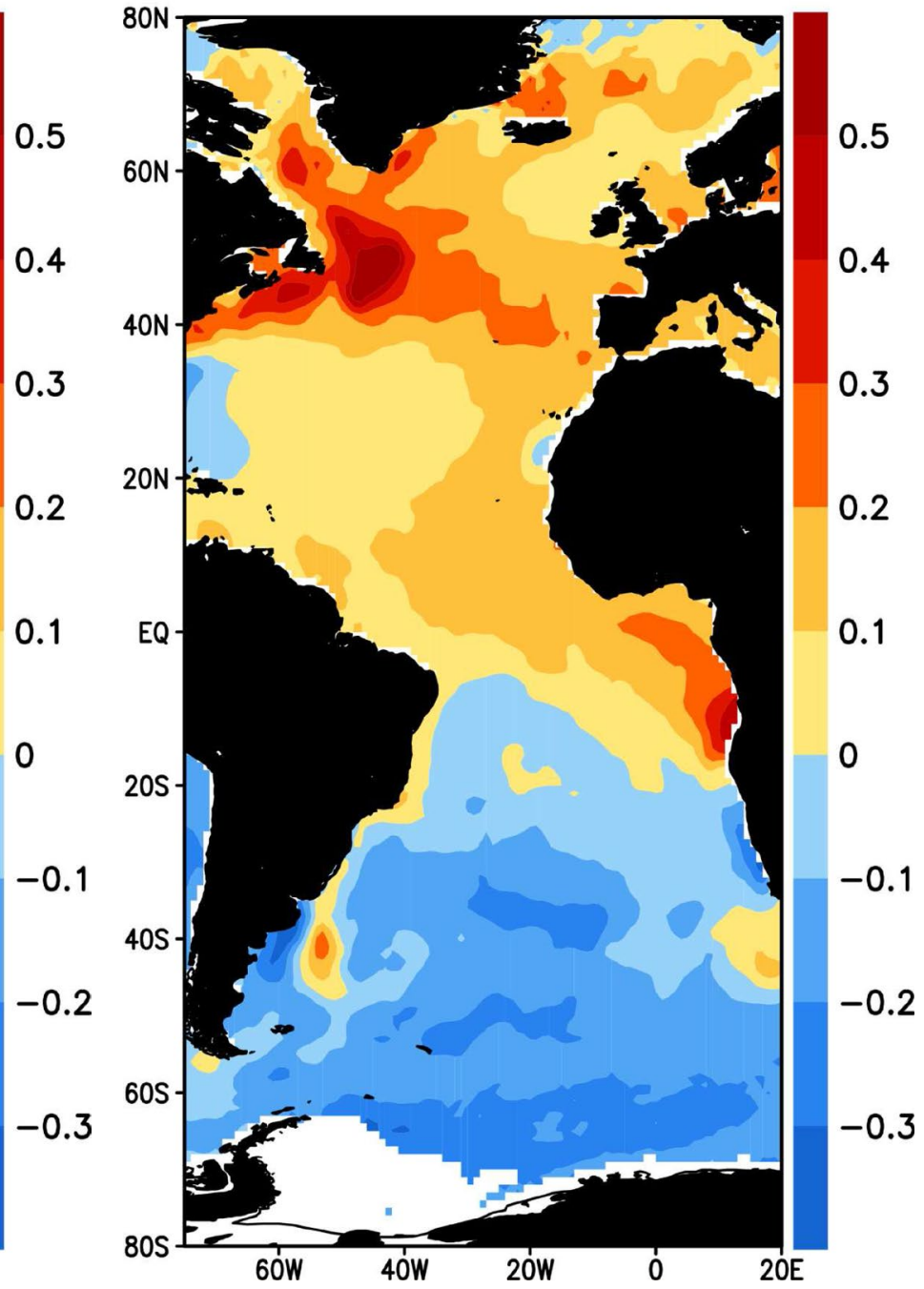

Fig. 1 Modes of Atlantic SST variability, derived through EOF analysis. a time component of the dominant SST mode (black line); b time component of the second dominant SST mode (black line); c the pattern of the dominant mode $\left({ }^{\circ} \mathrm{C}\right)$, explaining $21 \%$ of variance, associated with EOF1; $\mathbf{c}$ the pattern of the second dominant mode

$\left({ }^{\circ} \mathrm{C}\right)$, explaining $19 \%$ of variance, derived as linear combination of EOF2 and EOF3. In panels a and $\mathbf{c}$ are also shown the time components (blue lines) associated with the simulated SST Trend Mode and AMO, derived through EOF analysis, with patterns shown in Fig. 2. The time components are normalized with their standard deviations 
a) Simulated Trend Mode

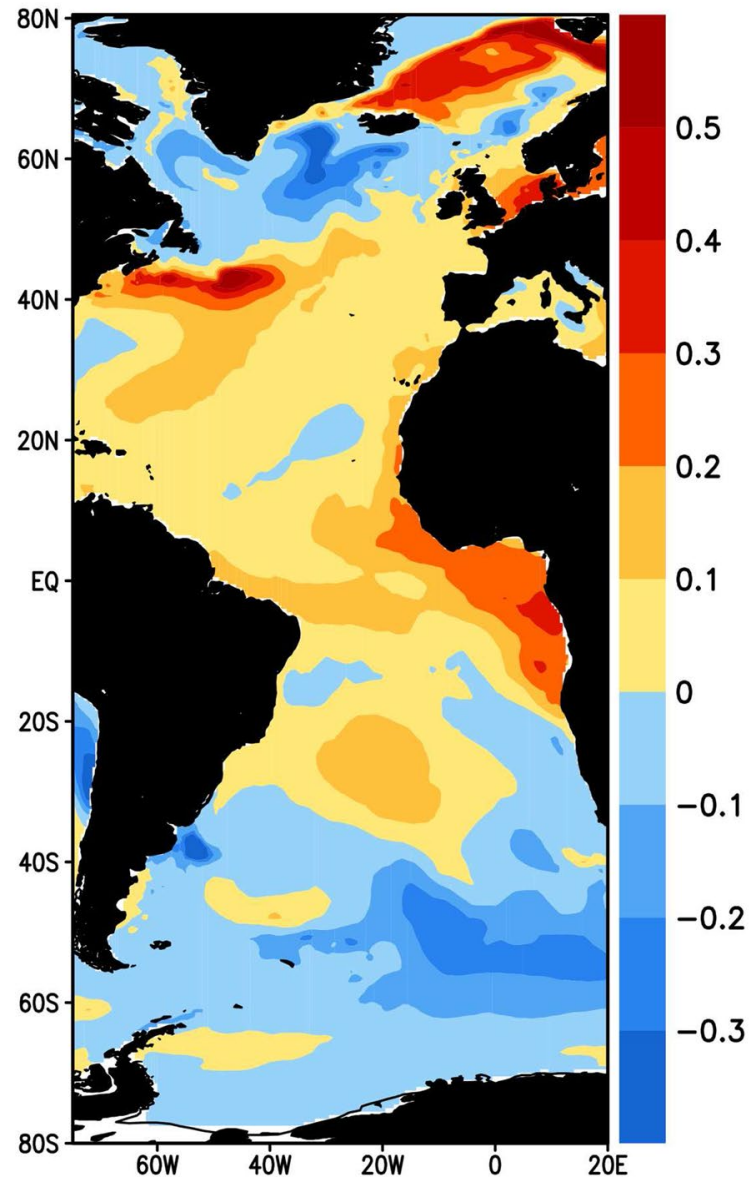

b) Simulated AMO

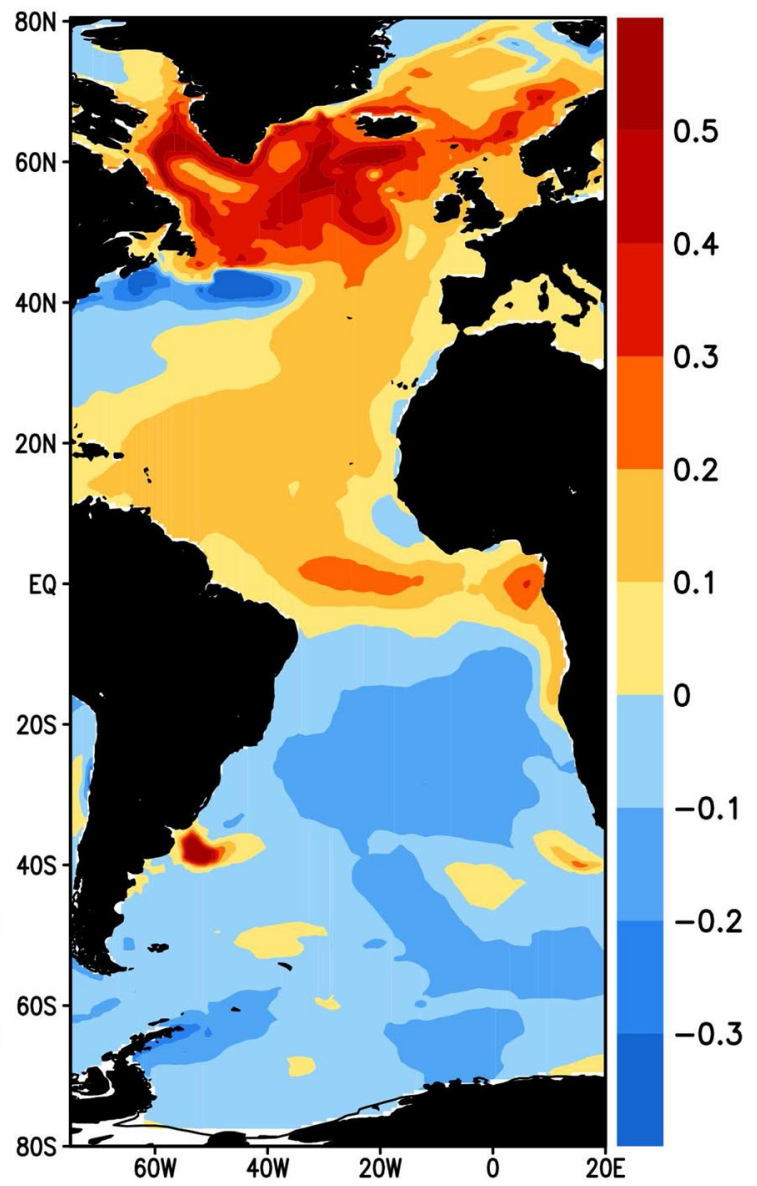

Fig. 2 Dominant modes of simulated Atlantic SSTs derived through EOF analysis. a the pattern of the EOF2 $\left({ }^{\circ} \mathrm{C}\right)$, explaining $13 \%$ of variance; $\mathbf{b}$ the pattern of EOF1 $\left({ }^{\circ} \mathrm{C}\right)$, explaining $19 \%$ of variance. The EOFs were multiplied with the standard deviations of the corresponding PCs

\subsection{Two distinct simulated AMOC modes}

In order to investigate the modes of AMOC variability, EOF analysis is performed also on the annual averages of zonal mean streamfunction for the meridional domain $\left(30^{\circ} \mathrm{S}-80^{\circ}\right.$ N. 0-5000 m depth).

The first five EOFs, explaining $80 \%$ of variance, are considered in our study (Fig. S2). Whereas PC1, PC2 and $\mathrm{PC} 4$ are characterized by growing trends over the analyzed period, PC3 and PC5 are marked by multidecadal fluctuations. Therefore, we consider that the former and the latter groups of PCs are describing two different modes. The stream function pattern of the first modes (associated with a trend) is obtained by adding EOF1, EOF2 and EOF4 (previously multiplied by the standard deviations of the corresponding PCs). The associated time component is obtained by adding the corresponding PCs (Fig. 3a). Hereafter this mode is referred also as the Trend Mode (TM), in correspondence with the analogue SST mode. In a similar manner are combined EOF3/PC3 and EOF5/PC5 in order to derive the pattern and the time component of the other mode. The $\mathrm{TM}$, explaining $60 \%$ of variance, is marked by a cell of negative anomalies centered at about $50^{\circ} \mathrm{N} / 1000 \mathrm{~m}$ depth and one with positive anomalies centered at $15^{\circ} \mathrm{S} / 1700 \mathrm{~m}$ (Fig. 3c). One notes that North Atlantic AMOC changes were linked with corresponding variations in the southern sector of this basin (Zhu and Liu 2020).

EOF3 and EOF5 (Fig. S3e, i) are marked by positive cells located between equator and $50^{\circ} \mathrm{N}$, whereas their PCs are modulated by multidecadal variability which includes a negative phase of negative values during the 1970s and 1980s (Fig. S3f, j). These common properties indicate that these two EOFs/PCs are associated with the same mode. Its pattern, explaining $21 \%$ of variance, is obtained by adding EOF3 and EOF5 (previously multiplied with the standard deviations of the corresponding PCs) and its time component is derived through the superposition of the corresponding normalized, PC3 and PC5. The AMOC pattern associated with this mode is marked by an overturning cell centered at about $20^{\circ} \mathrm{N} / 2000 \mathrm{~m}$ 

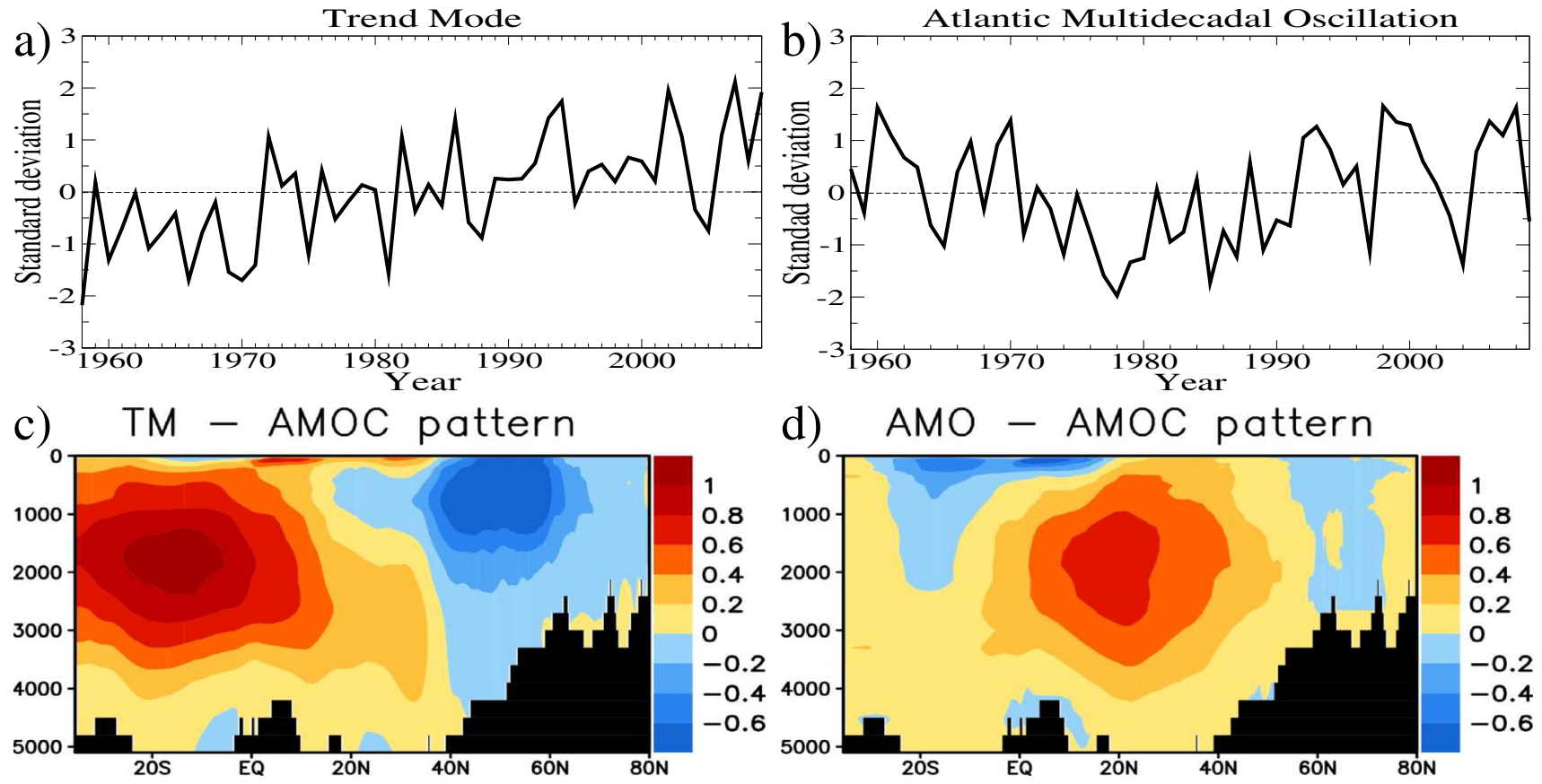

Fig. 3 Modes of simulated streamfunction variability derived through EOF analysis. a time component of the trend mode (sum of normalized PC1, PC2 and PC4); b time component of the multidecadal mode (sum of normalized PC3 and PC5); $\mathbf{c}$ the pattern of the trend mode (Sv), explaining $60 \%$ of variance, derived as linear combina-

depth (Fig. 3d). The amplitude of its variations is slightly larger than $1 \mathrm{~Sv}$. The associated time series shows the typical AMO fluctuations (Fig. 3b).

\subsection{Simulated Atlantic ocean surface footprints of the two AMOC modes}

In order to derive the simulated surface footprints of the two AMOC modes, we regressed their associated time components (Fig. 3a,b) on the SST field. The regression pattern (Fig. 4a) of the trend-like time component includes the main characteristics of the simulated SST trend mode: the tripole located in North Atlantic, the positive anomalies in South Atlantic to $60^{\circ} \mathrm{S}$ and negative anomalies southward (Fig. 4a), consistent with previous studies (e.g. Zhu and Liu 2020). Similarly, the regression map (Fig. 4b) of the second time component resembles closely the pattern of the simulated AMO SST pattern (Fig. 2b). Therefore, the structures of the two regression maps indicate that the two SST modes reflect changes corresponding to the two AMOC modes. Whereas the SST trend mode is linked to a weakening AMOC cell centered at $50^{\circ} \mathrm{N}$ and one located around $15^{\circ} \mathrm{S}$, AMO is connected to an AMOC cell centered around $20^{\circ} \mathrm{N}$.

tion of EOF1, EOF2 and EOF4, which are previously multiplied with the standard deviations of the corresponding PCs; $\mathbf{d}$ the pattern of the multidecadal mode (Sv), explaining $21 \%$ of variance, derived as linear combination of EOF3 and EOF5, which are previously multiplied with the standard deviations of the corresponding PCs

\subsection{Simulated modes of North Atlantic deep water formation}

In order to investigate potential links between NADWF sites and AMOC modes, an EOF analysis is performed on the simulated MLD field. The second dominant EOF, explainig $17 \%$ of variance, is marked by a center of maximum values located in the Nordic Seas (Fig. 5c). Its corresponding time series indicate decreasing mixed layer depth and therefore weakening convection, over the integration period (Fig. 5a). The dominant MLD mode, explaining 36\% of total variance, is marked by the center of maximum values located in the Labrador and Irminger Seas (Fig. 5d). Its time series (Fig. 5b) indicates reduced convection during the 1960s and after 1997, but maximum values in between these time intervals, in anti-correlation with the AMO time series (Fig. 3b). This indicates that this dominant MLD mode is linked with deep water formation in the Labrador and Irminger seas.

\subsection{Links between the two NADWF sites and the two AMOC modes}

In order to investigate possible connections between NADWF and the two AMOC modes, the time components associated with the dominating MLD modes (Fig. 5a, b) 


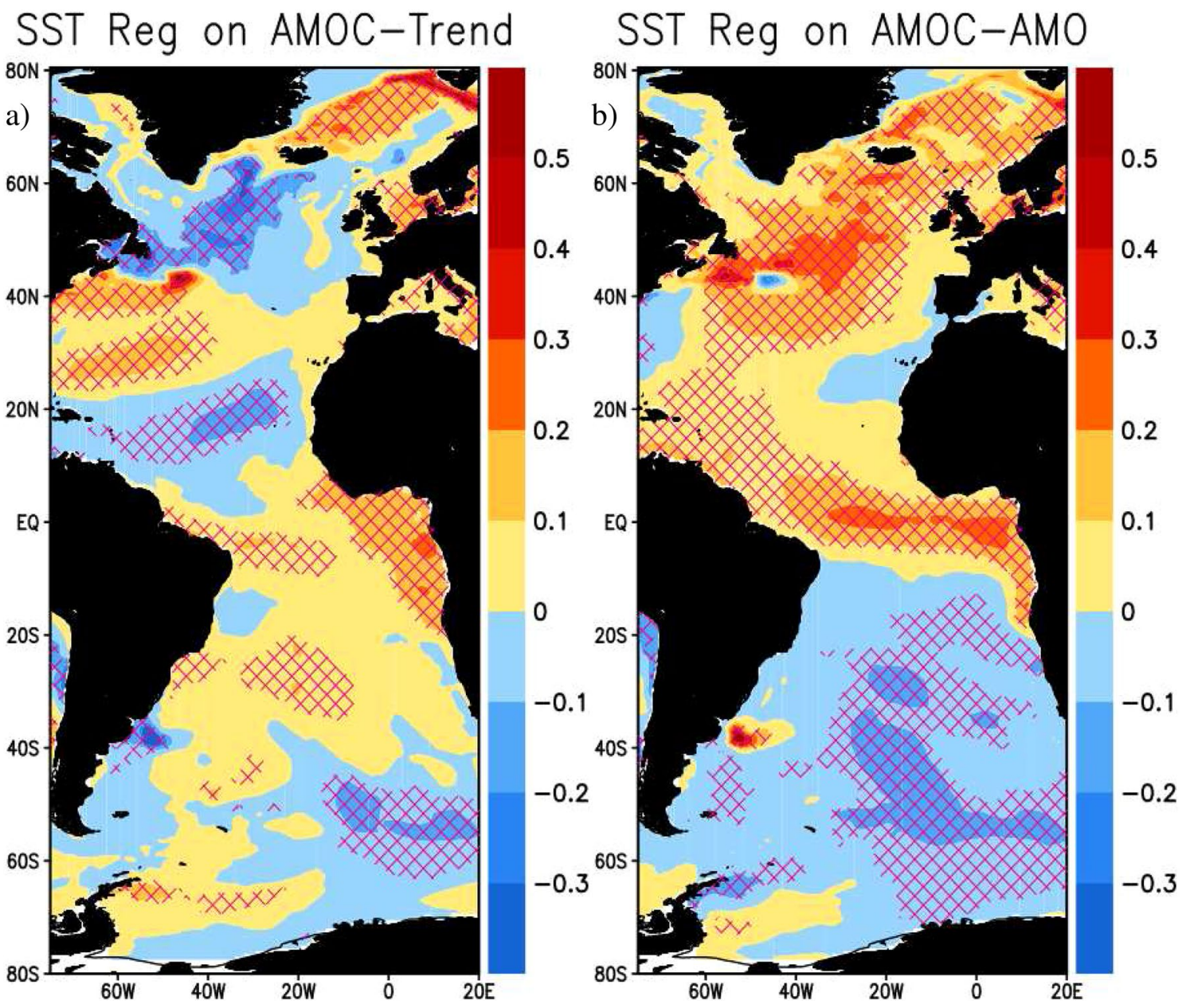

Fig. 4 Simulated regression SST patterns of the AMOC time components. a Regression map of the North Atlantic AMOC trend (Fig. 3a) on the SST field $\left({ }^{\circ} \mathrm{C} /\right.$ std.dev.); b Regression map of the AMOC

are regressed on the simulated Atlantic streamfunction and SST fields. The regression of the trend-like MLD time component (Fig. 5a) on the streamfunction field has maximum values when the last lags the former with 7 years. The regression pattern (Fig. 6a) includes the two centers of negative, respectively positive values, centered around $50^{\circ}$ $\mathrm{N}$ and $15^{\circ} \mathrm{S}$ (Fig. 3c). For a 8 year lag, the SST regression map includes the centers of alternating signs in North Atlantic, positive anomalies in subtropical South Atlantic and negative anomalies close to Antarctica (Fig. 6c), which are typical for the SST Trend Mode (Fig. 1c and Fig. 2a). The negative center located south of Greenland could be considered a response to the relatively weak AMOC cell located around $50^{\circ} \mathrm{N}$ (Fig. 3c and Fig. 6a). All mentioned features are significant at the $95 \%$ confidence level. Therefore, the decreasing MLD in the Nordic Seas (Fig. 5a, c) appears to be associated in North Atlantic with a reduced AMOC cell located around $50^{\circ} \mathrm{N}$ and negative SST anomalies south of Greenland (Fig. 6a, c). multidecadal component (Fig. 3b) on the SST field ( ${ }^{\circ} \mathrm{C} /$ std.dev.). The regions for which the regression is significant above the $95 \%$ confidence level are covered by red grids

Similarly, the regression of the time component of the dominant MLD mode (Fig. 6b) on the Atlantic stream function and SST fields show maximum values for lags of 9 years and 12 years, respectively. Whereas the stream function regression pattern (Fig. 6b) is dominated by a positive center located close to $20^{\circ} \mathrm{N}$, the SST corresponding structure (Fig. 6d) is marked by dominating positive SST anomalies in North Atlantic and negative loadings in the southern hemisphere sector of this basin. All features mentioned here are significant at the $95 \%$ confidence level. These indicate that changes in MLD in the Labrador and Irminger Seas are associated with an AMOC cell centered around $20^{\circ} \mathrm{N}$ and a monopolar North Atlantic SST pattern. These associations between the AMOC structures and the SST patterns corresponding to TM and AMO are also derived through a Canonical Correlation Analysis (CCA) (Fig. S4).

In synthesis, the EOF, CCA and regression analyses of the simulated SST, MLD and AMOC fields indicate that each of the two SST modes is linked with a distinct North 

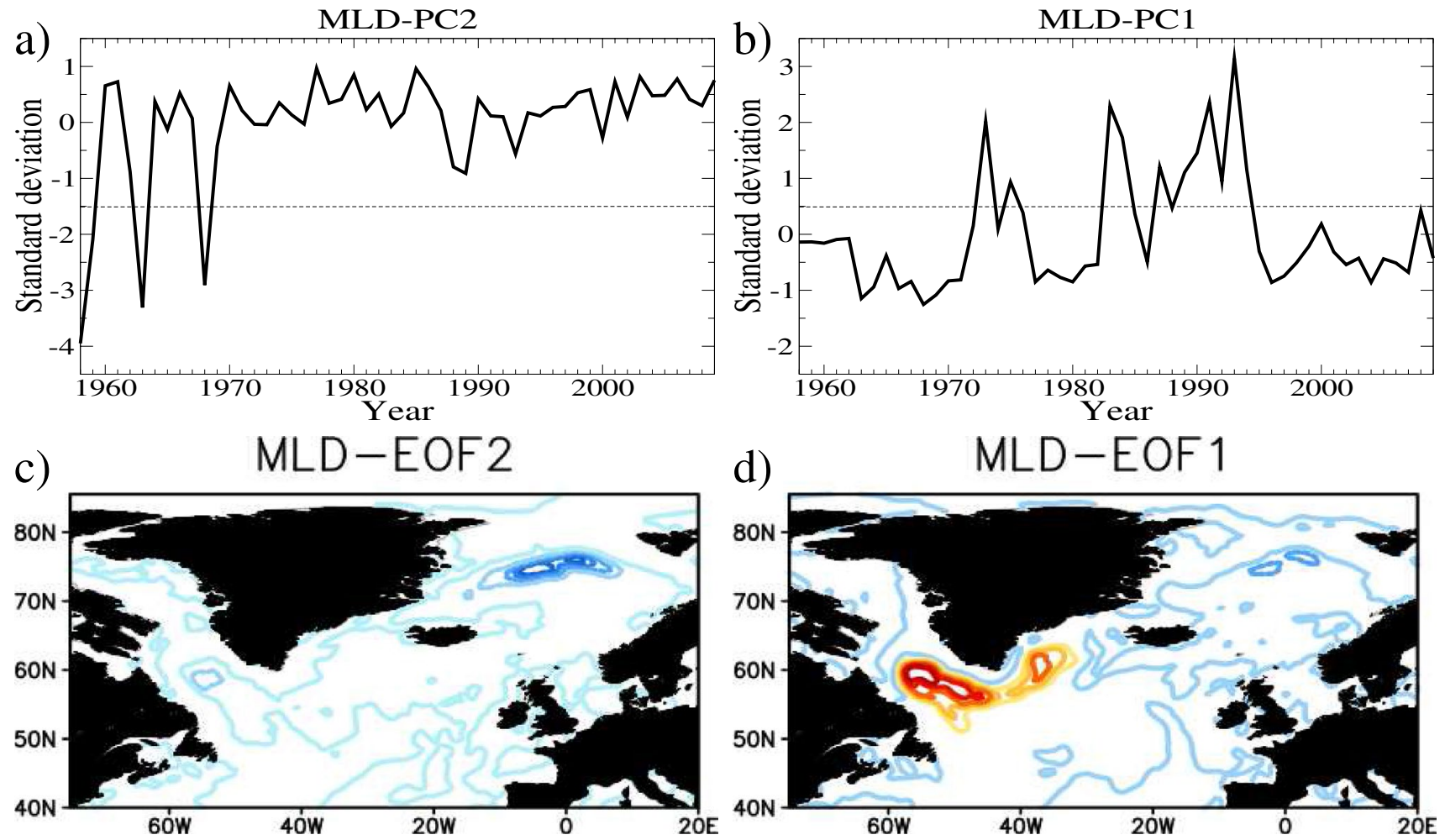

Fig. 5 Dominant modes of simulated North Atlantic DJF MLD. a Time evolution of the normalized time component associated to EOF2; $\mathbf{b}$ Time evolution of the normalized time component associated to EOF1; c EOF2, explaining $17 \%$ of variance, multiplied by

Atlantic deep water formation region: whereas TM is connected with NSDWF, AMO is linked with LISDWF.

\section{Discussion}

These results provide constraints about the physical mechanisms linking the deep water formation in the two regions with the corresponding AMOC cells and SST patterns. At long time scales, the lowest part of the Deep Western Boundary Current (DWBC), which propagates westward and then southward, is fed by the Nordic Seas overflow system, which has a significant influence on AMOC (Hawkins and Sutton 2008). A downslope of DWBC in the deep ocean levels could result in the bottom vortex stretching with corresponding ocean surface changes on the Northern Recirculation Gyre, associated with adjustment of the Gulf Stream position (Zhang and Vallis 2007, Born et al. 2009; Zhang et al. 2011; Langehaug et al. 2012, Yeager and Danabasoglu 2012). Through geostrophic balance, an anomalous DWBC affects also the subpolar AMOC cell. These processes, could generate the North Atlantic SST dipole, which marks the SST pattern of TM (Fig. 1c).

the standard deviation of MLD (contour interval is $50 \mathrm{~m}$ ); $\mathbf{d}$ EOF1, explaining $36 \%$ of variance, multiplied by the standard deviation of MLD (contour interval is $50 \mathrm{~m}$ )

Positive density anomalies in LISDWF, which results in an intensified upper limb of DWBC and an associated AMOC strengthening through geostrophic balance, generates a relatively strong circulation in the Gulf Stream (Langehaug et al. 2012; Yeager and Danabasoglu 2012; Wouters et al. 2012; Ortega et al. 2016). Its relatively warm waters spread eastward over North Atlantic along the surface currents and generates the horseshoe pattern of AMO (Fig. 1b) in about 7 years, as was shown based on observational data (Sutton and Allen 1997; Dima and Lohmann 2004). One notes that the North Atlantic AMOC cell of TM (Fig. 3c) is located northward relative to the corresponding cell of AMO (Fig. 3d), consistent with the fact that the location of the forcing factor of the former, NSDWF, is also located further northward than the LISDWF. Conistent with this, numerical simulations indicate that while decadal AMOC variations as that associated with AMO are forced by flux anomalies in the subpolar North Atlantic, longer time scales AMOC changes originates further north, in the Arctic (Sevellec et al. 2017).

Previous studies emphasize a significant role of LISDWF in forcing AMOC changes (Eden and Willebrand 2001; Bailey et al. 2005; Getzlaff et al. 2005, Danabasolu et al. 2012). However, it was argued that at interannual and decadal time 
a) $\mathrm{AMOC} \operatorname{Reg}$ on MLD-PC2

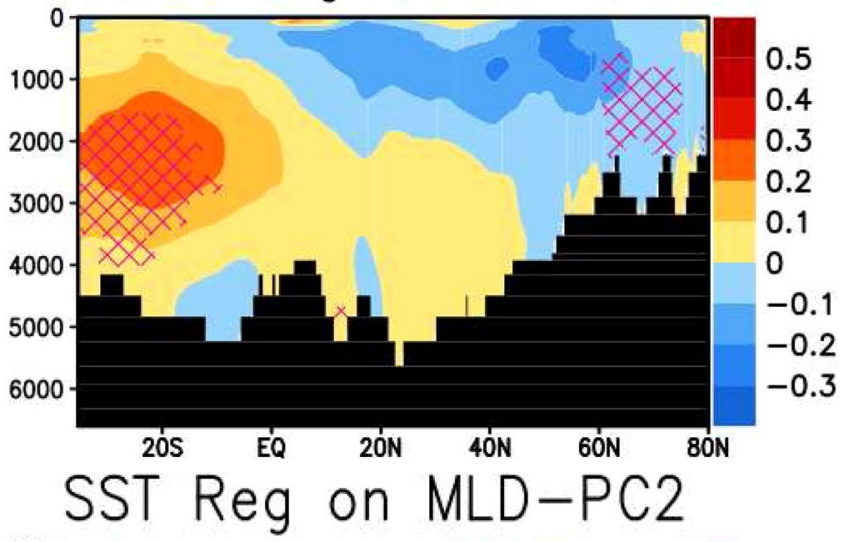

c)
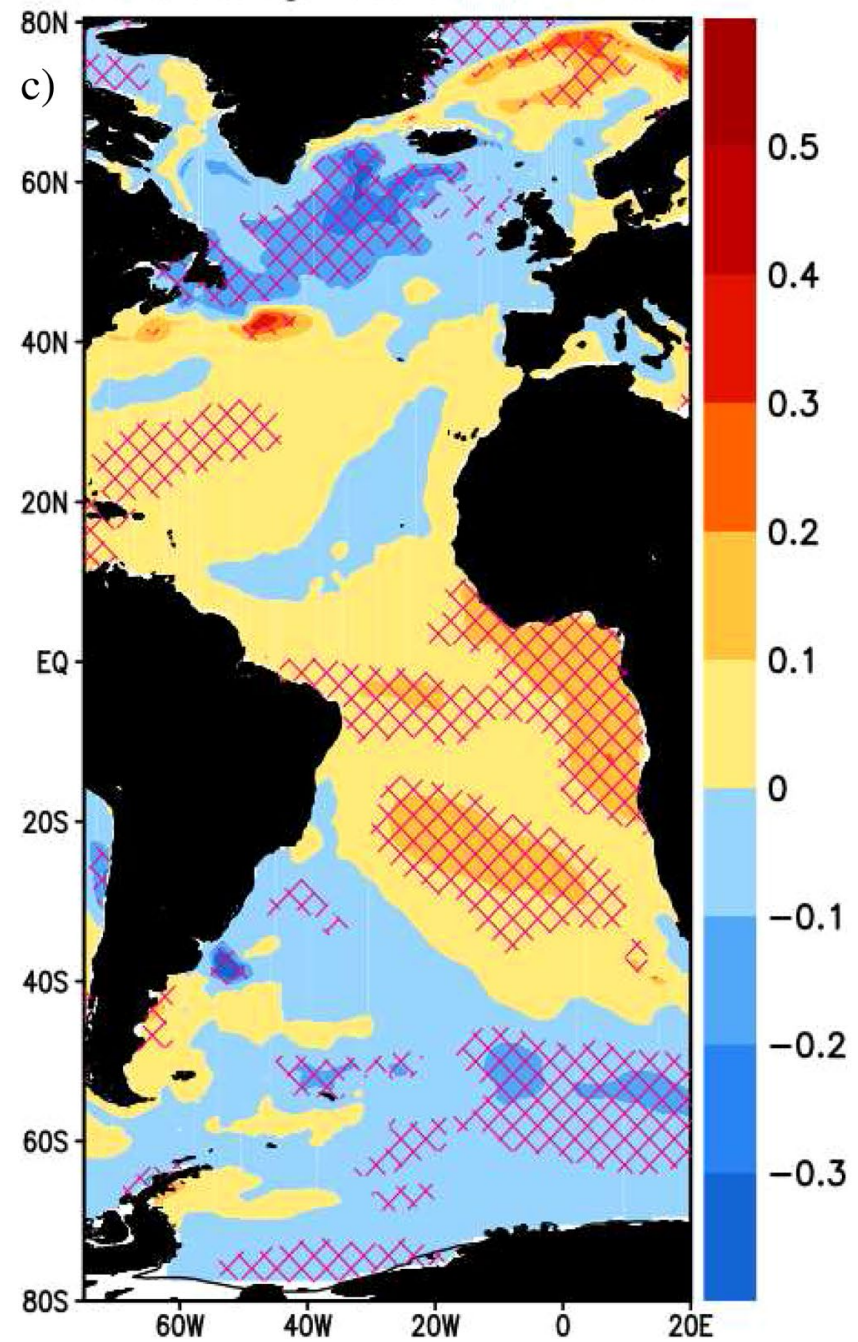

Fig. 6 Links between NADWF sites and AMOC/SST modes. a Regression map of the North Atlantic MLD-PC2 (Fig. 5a) on the streamfunction field (Sv/std.dev.); the former leads by 7 years; b Regression map of the North Atlantic MLD-PC1 (Fig. 5b) on the streamfunction field (Sv/std.dev.); the former leads by 9 years; $c$ b) AMOC Reg on MLD-PC1
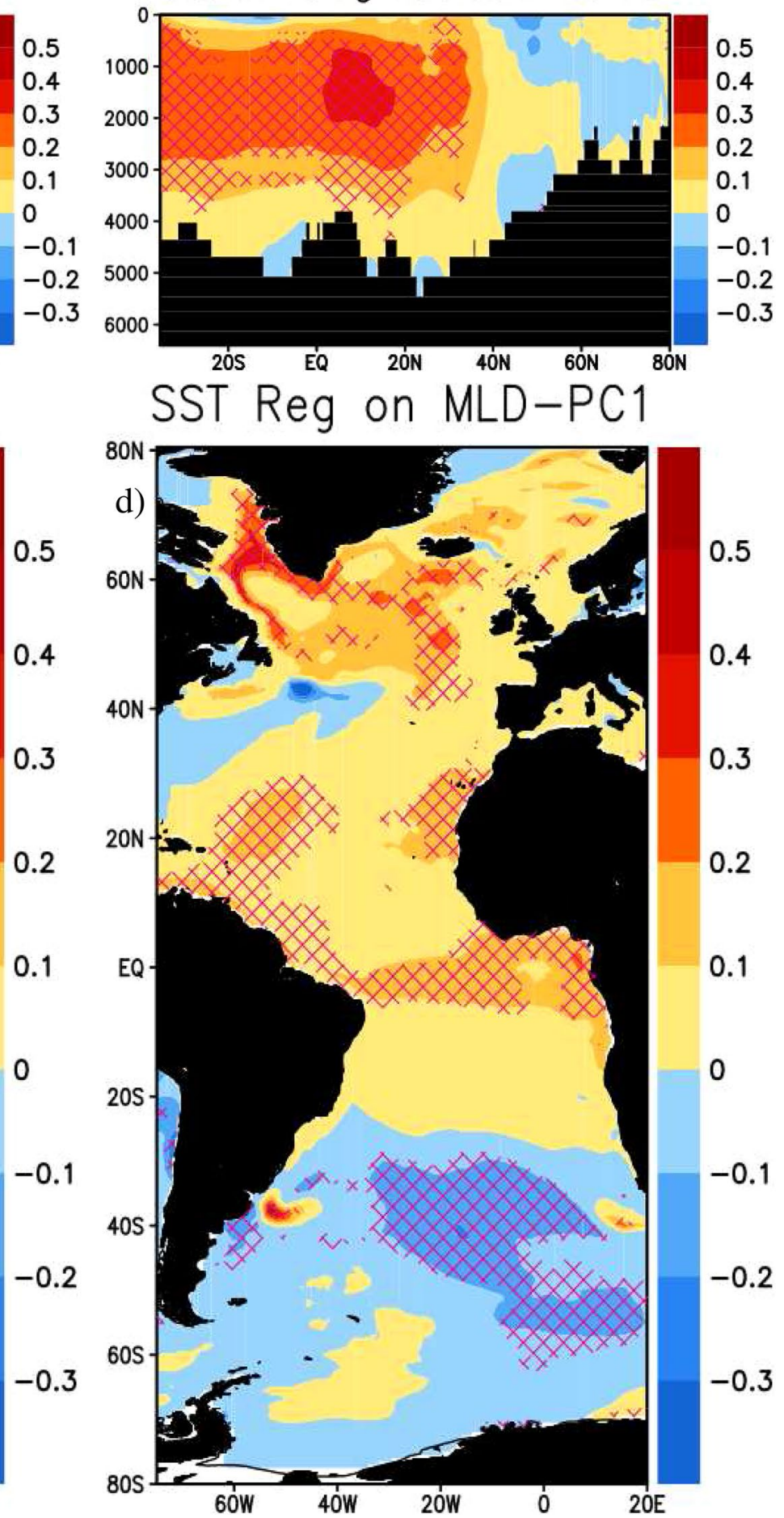

Regression map of the North Atlantic MLD-PC2 (Fig. 5a) on the SST field $\left({ }^{\circ} \mathrm{C} /\right.$ std.dev.); the former leads by 8 years; $\mathbf{d}$ Regression map of the North Atlantic MLD-PC1 (Fig. 5b) on the SST field ( ${ }^{\circ} \mathrm{C} /$ std.dev.); the former leads by 12 years. The regions for which the regression is significant above the $95 \%$ confidence level are covered by red grids 
scales, changes in Labrador Sea water volume are not clearly linked with MOC response across latitudes ( $\mathrm{Li}$ et al. 2019). This apparent contradiction was reconciled by suggesting that the Labrador density anomalies, which were linked with AMOC changes, are originating in the Irminger Sea. In this last region, surface foring generates density anomalies which propagate in the Labrador Sea, where they dominate the variations of this variable (Menary et al. 2020). In our study, the dominant North Atlantic MLD mode includes large loading over both, Labrador and Irminger Seas (Fig. 5d), and therefore there is no distinction between changes in water properties in these two seas.

Based on analyses of ocean data from the Overturning in the Subpolar North Atlantic Program (OSNAP), for August 2014 to April 2016, it was suggested that the transformation of warm, salty shallow waters into cold, fresh deep waters moving southward in the Irminger and Iceland basins are largely responsible for the overturning variability in the subpolar North Atlantic (Lozier et al. 2019). By linking the NSDWF with the subpolar AMOC cell, our study reinforces this result.

In our simulation with the ocean model, the TM and AMO are explaining comparable amount of variance in the North Atlantic stream function field, but their associated North Atlantic AMOC cells are centered at different latitudes, at $50^{\circ} \mathrm{N}$ and $20^{\circ} \mathrm{N}$, respectively. Consistent with this, a dual temporal manifestation of North Atlantic meridional circulation was reported in a model integration in which a fluctuation between AMO phases was associated with an anomalous AMOC cell centered at $20^{\circ} \mathrm{N}$ (Lozier et al. 2010).

In numerical simulations, the LISDWF appears to impact significantly AMOC in the subtropics only in models with "eddy-permitting" resolution (Getzlaff et al. 2005). The AMOC response in the subtropics appear to result from a superposition of a fast dynamical adjustment through waves propagation and a southward advective mass propagation.

If the essential mechanisms for Dandgaard-Oeschger (DO) events, characterized by rapid warmings in North Atlantic during glacial periods, likely linked with AMOC changes (e.g. Dima et al. 2018), are the known processes which operate on different (glacial) background conditions ( $\mathrm{Li}$ and Born 2019), then the links proposed in our study can contribute to the understanding of mechanisms of past climate changes and projections of future AMOC evolution. For example, as the TM is linked to NSDWF, which is covered by sea ice during glacial times, this mode could provide the background stable cold state of AMOC, consistent with its relative long characteristic time scale over the instrumental period. The LSDWF is closer to the southern limit of sea ice which could insulate the ocean circulation from atmospheric forcing in a more variable manner. Therefore, the AMO-AMOC mode is more likely to play an active role in DO fluctuations, as was suggested (Dima and Lohmann 2010). Regarding the future AMOC evolution, the suppression of Labrador convection under global warming (Wood et al. 1999; Brodeau and Koenigk 2016) before a full AMOC shutdown, implies a cessation of AMO.

\section{Conclusions}

The main goal of this study was to identify the origin of the different manifestations of two AMOC modes, as reflected on the SST field. The observational and numerical results presented here, indicate that the origin of the distinction between the two AMOC modes is linked with their associations with different North Atlantic deep water formation sites. Whereas the centennial TM is associated with NSDWF, AMO is essentially linked with LISDWF. While changes in NSDWF are reflected in North Atlantic through an overturning cell centered at $50^{\circ} \mathrm{N}$, variations in LISDWF is linked with an $\mathrm{AMOC}$ cell centered at $20^{\circ} \mathrm{N}$. Our results are consistent with previous studies which identifies the North Atlantic subpolar SSTs, on which the North Atlantic cell associated with TM has strong impact, as an indicator of long-term AMOC changes (Dima and Lohmann 2010; Rahmstorf et al. 2015; Caesar et al. 2018).

The North Atlantic AMOC cell of TM was emphasized as a northward intensification of anthropogenically forced AMOC changes, through a coupled model twenty-first century simulation performed under the A1B scenario, which does not include any changes in solar irradiance and volcanic aerosols (Zhang 2010). Together with our results, this implies that the centennial scale AMOC weakening trend, which was linked with increasing atmospheric $\mathrm{CO}_{2}$ concentration forcing (Caesar et al. 2018; Dima et al. 2021), is linked with the NSDWF and with the subpolar North Atlantic AMOC cell. Our results are in line with previous suggestion that the main element which governs the AMOC response to global warming is the density of intermediate waters in the Greenland-Iceland-Norwegian Seas, which influences the density of North Atlantic deep water (Schweckendiek and Willebrand 2005).

Supplementary Information The online version contains supplementary material available at https://doi.org/10.1007/s00382-022-06156-w.

Funding Open Access funding enabled and organized by Projekt DEAL. GL, MI, GK and PS are supported by Helmholtz funding through the joint program "Changing Earth-Sustaining our Future" (PoF IV) program of the AWI. Funding by the Helmholtz Climate Initiative REKLIM, the BMBF project PalMod and the project S2: Improved parametrisations and numerics in climate models, of the collaborative Research Center TRR181 "Energy Trasnfer in the Atmosphere and Ocean" (DFG)—Projecktnummer 274762653 are gratefully acknowledged. Mihai Dima was funded by the Humboldt Foundation 
and the visiting program of the Alfred Wegener Institute. The data used are listed in the references.

Availability of data and material The datasets for this research are described in these papers: Huang et al. (2015), Rayner et al. (2003), Scholz et al. (2013), Scholz et al. (2014).

\section{Declarations}

Conflict of interest Not applicable.

Ethical approval Not applicable.

Consent to participate Not applicable.

Consent for publication Not applicable.

Open Access This article is licensed under a Creative Commons Attribution 4.0 International License, which permits use, sharing, adaptation, distribution and reproduction in any medium or format, as long as you give appropriate credit to the original author(s) and the source, provide a link to the Creative Commons licence, and indicate if changes were made. The images or other third party material in this article are included in the article's Creative Commons licence, unless indicated otherwise in a credit line to the material. If material is not included in the article's Creative Commons licence and your intended use is not permitted by statutory regulation or exceeds the permitted use, you will need to obtain permission directly from the copyright holder. To view a copy of this licence, visit http://creativecommons.org/licenses/by/4.0/.

\section{References}

Bailey DA, Rhines PB, Häkkinen S (2005) Formation and pathways of North Atlantic Deep Water in a coupled ice-ocean model of the Arctic-North Atlantic Oceans. Clim Dyn 25:497-516. https://doi. org/10.1007/s00382-005-0050-3

Born A, Levermann A, Mignot J (2009) Sensitivity of the Atlantic Ocean circulation to a hydraulic overflow parametrisation in a coarse resolution model: Response of the subpolar gyre. Oc Modelling 27:130-142. https://www.sciencedirect.com/science/article/ pii/S1463500308001765

Brodeau L, Koenigk T (2016) Extinction of the northern oceanic deep convection in an ensemble of climate model simulation of the 20th and 21st centuries. Clim Dyn 46:2863-2882. https://doi.org/10. 1007/s00382-015-2736-5

Bryden HL, Longworth HR, Cunningham SA (2005) Slowing of the Atlantic meridional overturning circulation at $25^{\circ} \mathrm{N}$. Nature 438:655-657. https://www.nature.com/articles/nature04385

Buckley MW, Marshall J (2016) Observations, inferences, and mechanisms of Atlantic Meridional Overturning Circulation variability: a review. Rev Geophy 54:5-63. https://doi.org/10.1002/2015R G000493

Caesar L, Rahmstorf S, Robinson A, Feulner G, Saba V (2018) Observed fingerprint of a weakening Atlantic Ocean overturning circulation. Nature 556:191-196. https://www.nature.com/artic les/s41586-018-0006-5

Caesar L, McCarthy GD, Thornalley DJR, Cahill N, Rahmstorf S (2021) Current Atlantic Meridional Overturning Circulation weakest in the last millennium. Nat Geosci 14:118-120. https:// doi.org/10.1038/s41561-021-00699-z
Cheng W, Chiang JCH, Zhang D (2013) Atlantic Meridional Overturning Circulation (AMOC) in CMIP5 Models: RCP and Historical Simulations. J Clim 26:7187-7197. https://journals.ametsoc.org/ jcli/article/26/18/7187/34401/Atlantic-Meridional-OverturningCirculation-AMOC

Collins M, Knutti R, Arblaster J, Dufresne J-L, Fichefet T, Friedlingstein P, et al. (2013) Long-term climate change: Projections, commitments and irreversibility. In: TF Stocker, D Qin, G-K Plattner, M Tignor, SK Allen, J Doschung, A Nauels, Y Xia, V Bex, PM Midgley (eds) Climate Change 2013: The Physical Science Basis. Contribution of Working Group I to the Fifth Assessment Report of the Intergovernmental Panel on Climate Change, Cambridge University Press, USA, pp. 1029-1136, doi:https://doi.org/10. 1017/CBO9781107415324.024. https://www.ipcc.ch/site/assets/ uploads/2018/02/WG1AR5_Chapter12_FINAL.pdf

Collins M, Sutherland M, Bouwer L, Cheong S-M, Frölicher T, Jacot Des Combes H, et al. (2019) Extremes, Abrupt Changes and Managing Risk. In: IPCC Special Report on the Ocean and Cryosphere in a Changing Climate. [H.-O. Pörtner, D.C. Roberts, V. Masson-Delmotte, P. Zhai, M. Tignor, E. Poloczanska, K. Mintenbeck, A. Alegría, M. Nicolai, A. Okem, J. Petzold, B. Rama, N.M. Weyer (eds.)] https://www.ipcc.ch/srocc/chapt er/chapter-6/

Danabasoglu G, Yeager SG, Kwon YO, Tribbia JJ, Phillips AS, Hurrel JW (2012) Variability of the Atlantic Meridional Overturning Circulation in CCSM4, J. Climate, 25, 5153-5171. https://journ als.ametsoc.org/view/journals/clim/25/15/jcli-d-11-00463.1.xml

Dima M, Lohmann G (2004) Fundamental and derived modes of climate variability: concept and application to interannual timesclaes. Tellus 56A:229-249. https://doi.org/10.3402/tellusa.v56i3. 14415

Dima M, Lohmann G (2007) A hemispheric mechanism for the atlantic multidecadal oscillation. J Clima 20:2706-2719. https://journals. ametsoc.org/jcli/article/20/11/2706/30902/A-Hemispheric-Mecha nism-for-the-Atlantic

Dima M, Lohmann G (2010) Evidence for two Distinct Modes of Large-Scale Ocean Circulation Changes over the Last Century. J Clim 23:5-16. https://journals.ametsoc.org/jcli/article/23/1/5/ 32258/Evidence-for-Two-Distinct-Modes-of-Large-Scale

Dima M, Lohmann G (2011) Hysteresis behavior of the Atlantic Ocean Circulation Identified in observational data. J Clim 24:397-403. https://journals.ametsoc.org/jcli/article/24/2/397/33407/Hyste resis-Behavior-of-the-Atlantic-Ocean

Dima M, Lohmann G, Knorr G (2018) North Atlantic versus global control on Dansgaard-Oeschger events. Geophys Res Lett. 45:12,991-12,998. https://epic.awi.de/id/eprint/49330/1/dima_ lohmann_knorr_do_hyteresis_grl_2018.pdf

Dima M, Nichita DR, Lohmann G, Ionita M, Voiculescu M (2021) Early-onset of Atlantic Meridional Overturning Circulation weakening in response to atmospheric $\mathrm{CO}_{2}$ concentration. npj Climate and Atmospheric Science 4:27. https://www.nature.com/articles/ s41612-021-00182-xs41612-021-00182-x

Drijfhout S, van Oldenborgh GJ, Cimatoribus A (2012) Is a decline of AMOC causing the warming hole above the North Atlantic in observed and modeled warming patterns?. J Clim 25(24):83738379, doi:https://doi.org/10.1175/JCLI-D-12-00490.1. https:// journals.ametsoc.org/jcli/article/25/24/8373/33671/Is-a-Decli ne-of-AMOC-Causing-the-Warming-Hole

Eden C, Willebrand J (2001) Mechanism of Interannual to Decadal Variability of the North Atlantic Circulation. J Climate 14:22662280. https://journals.ametsoc.org/view/journals/clim/14/10/ 1520-0442_2001_014_2266_moitdv_2.0.co_2.xml

Getzlaff J, Böning CW, Eden C, Biastoch A (2005) Signal propagation related to the North Atlantic overurning. Geophys Res Lett 32:L09602. https://doi.org/10.1029/2004GL021002 
Hawkins E, Sutton R (2008) Potential predictability of rapid changes in the Atlantic meridional overturning circulation. Geophys Res Lett. https://doi.org/10.1029/2008GL034059

Huang B, Banzon VF, Freeman E, Lawrimore J, Liu W, Peterson TC, et al (2015) Extended Reconstructed Sea Surface Temperature version 4 (ERSST.v4): Part I. Upgrades and intercomparisons, J Clim 28:911-930. https://journals.ametsoc.org/jcli/article/28/3/ 911/106716/Extended-Reconstructed-Sea-Surface-Temperature

Ionita M, Scholz P, Lohmann G, Dima M, Prange M (2016) Linkages between atmospheric blocking sea ice export through Fram Strait and the Atlantic Meridional Overturning Circulation. Sci Rep DOI: https://doi.org/10.1038/SREP32881. https://www.nature. com/articles/srep32881

Jungclaus JH, Haak H, Latif M, Mikolajewicz U (2005) Arctic-North Atlantic Interactions and Multidecadal variability of the meridional overturning circulation. J Clim 18: 4013-4031. https://journ als.ametsoc.org/view/journals/clim/18/19/jcli3462.1.xml

Knight JR, Allan RJ, Folland CK, Vellinga M, Mann ME (2005) A signature of persistent natural thermohaline circulation cycles in observed climate. Geophys Res Lett 32:L20708. https://doi.org/ 10.1029/2005GL024233

Knorr G, Lohmann G (2007) Rapid transitions in the Atlantic thermohaline circulation triggered by global warming and meltwater during the last deglaciation. Geochem Geophys Geosys 8(12):1-22. https://doi.org/10.1029/2007GC001604

Kuhlbrodt T, Griesel A, Montoya M, Levermann A, Hofmann M, Rahmstorf S (2007) On the driving processes of the Atlantic meridional overturning circulation. Rev Geophys 45:2001. https:// doi.org/10.1029/2004RG000166

Langehaug H, Medhaug RI, Eldevik T, Ottera OH (2012) Arctic/Atlantic exchanges via the subpolar gyre. J Clim 25:2421-2439. https:// journals.ametsoc.org/jcli/article/25/7/2421/34065/Arctic-AtlanticExchanges-via-the-Subpolar-Gyre

Latif M, Roeckner E, Botzet M, Esch M, Haak H, Hagemann S, et al. (2004) Reconstructing, Monitoring, and Predicting MultidecadalScale Changes in the North Atlantic Thermohaline Circulation with Sea Surface Temperature, J Clim 17:1605-1614. https:// journals.ametsoc.org/jcli/article/17/7/1605/30540/Reconstruc ting-Monitoring-and-Predicting

Latif M, Boning C, Willebrand J, Biastoch A, Dengg J, Keenlyside et al. (2006) Is the thermohaline circulation changing? J Clim 19:4631-4637. https://journals.ametsoc.org/jcli/article/19/18/ 4631/31153/Is-the-Thermohaline-Circulation-Changing

Lenton TM, Held H, Kriegler E, Hall JW, Lucht W, Rahmstorf S et al. (2008) Tipping elements in the Earth's climate system, PNAS 105(6):1786-1793. https://www.pnas.org/content/105/6/1786

Li C, Born A (2019) Coupled atmosphere-ice-ocean dynamics in Dansgaard-Oeschger events. Quaternary Science Reviews, 203:120. https://www.sciencedirect.com/science/article/pii/S027737911 8305705

Li, X, Holland, D. M, Gerber, E. P, \& Yoo, C. (2014). Impacts of the north and tropical Atlantic Ocean on the Antarctic Peninsula and sea ice. Nature 23:538-542. https://www.nature.com/articles/natur e12945

Li F, Lozier MS, Danabasoglu G, Holliday NP, Kwon YO, Romanou A, Yeager SG, Zhang R (2019) Local and Downstream Relationship between Labrador Sea Water Volume and North Atlantic Meridional Overturning Circulation Variability. J Climate, 32:3883-3898. https://journals.ametsoc.org/view/journals/clim/ 32/13/jcli-d-18-0735.1.xml

Liu W, Xie SP, Liu Z, Zhu J (2017) Overlooked possibility of a collapsed Atlantic Meridional Overturning Circulation in a warming climate. Sci Adv 3:e1601666. https://advances.sciencemag.org/ content/3/1/e1601666

Lohmann G, Haak H, Jungclaus JH (2008) Estimating trends of Atlantic meridional overturning circulation from long-term hydrographic data and model simulations. Oc Dyn 58(2):127-138. https://doi.org/10.1007/s10236-008-0136-7.pdf

Lozier MS et al. (2019) A sea change in our view of overturning in the subpolar North Atlantic. Science, 363:516-521. https://science. sciencemag.org/content/363/6426/516

Lozier MS, Roussenov V, Reed MSC, Williams RG (2010) Opposing decadal changes for the North Atlantic meridional overturning circulation. Nature Geosci, 3:728-733. https://www.nature.com/ articles/ngeo947

Marini C, Frankignoul C (2014) An attempt to deconstruct the Atlantic Multidecadal oscillation. Clim Dyn 43:607-625. https://doi.org/ 10.1007/s00382-013-1852-3

Marshall J, Armour KC, Scott JR, Kostov Y, Hausmann U, Ferreira D et al (2014) The ocean's role in polar climate change: Asymmetric Arctic and Antarctic responses to greenhouse gas and ozone forcing. Phil Trans R Soc A 372(2019):20130040. https://doi.org/10. 1098/rsta.2013.0040

Menary MB, Jackson LC, Lozier MS (2020) Reconciling the relationship between the AMOC and labrador sea in OSNAP observations and climate models. Geophys Res Lett. https://doi.org/10.1029/ 2020GL089793

Ortega P, Robson J, Sutton RT, Andrews MB (2016) Mechanisms of decadal variability in the Labrador Sea and the wider North Atlantic in a high-resolution climate model. Clim Dyn 49:2625-2647. https://doi.org/10.1007/s00382-016-3467-y

Park W, Latif M (2008) Multidecadal and multicentenial variability of the meridional overturning circulation. Geophys Res Lett. https:// doi.org/10.1029/2008GL035779

Rahmstorf S (1995) Bifurcations of the Atlantic thermohaline circulation in response to changes in the hydrological cycle. Nature 379:145-149. https://www.nature.com/articles/378145a0

Rahmstorf S, Box JE, Feulner G, Mann ME, Robinson A, Sutherford S et al. (2015) Exceptional twentieth-century slowdown in Atlantic Ocean overturning circulation. Nat Clim Change 5(5):475-480. https://www.nature.com/articles/nclimate2554

Rayner NA, Parker DE, Horton EB, Folland CK, Alexander LV, Rowell DP et al (2003) Global analyses of sea surface temperature, sea ice, and night marine air temperature since the late nineteenth century. J Geophys Res Atm 108(D14):4407. https://doi.org/10. 1029/2002JD002670

Schlesinger ME, Ramankutty N (1994) An oscillation in the global climate system of period 65-70 years. Nature 367:723-726. https:// www.nature.com/articles/367723a0

Schmidt TH, Yang S, Gleeson E, Semmler T (2014) How Much Have Variations in the Meridional Overturning Circulation Contributed to Sea Surface Temperature Trends since 1850? A Study with the EC-Earth Global Climate Model. J Clim 27:6343-6357

Scholz P, Lohmann G, Wang Q, Danilov S (2013) Evaluation of a Finite-Element Sea-Ice Ocean Model (FESOM) set-up to study the interannual to decadal variability in the deep-water formation rates. Oc Dyn 63(4):347-370. https://doi.org/10.1007/ s10236-012-0590-0

Scholz P, Kieke D, Lohmann G, Ionita M, Rhein M (2014) Evaluation of Labrador Sea Water formation in a global Finite-Element SeaIce Ocean Model setup, based on a comparison with observational data. J Geophys Res Oc 119 (3):1644-1667. https://doi.org/10. 1002/2013JC009232. https://link.springer.com/article/10.1007\% 2Fs 10236-012-0590-0

Schweckendiek U, Willebrand J (2005) Mechanisms Affecting the Overturning Response in Global Warming Simulations. J Climate, 18:4925-4936. https://journals.ametsoc.org/view/journals/clim/ 18/23/jcli3550.1.xml

Sevellec F, Fedorov AV, Liu W (2017) Arctic sea-ice decline weakens the Atlantic Meridional Overturning Circulation. Nat Clim, 7:604-612. https://www.nature.com/articles/nclimate3353 
Smeed DA, McCarthy GD, Cunningham SA, Frajka-Williams E, Rayner D, Johns WE et al (2014) Observed decline of the Atlantic meridional overturning circulation 2004-2012. Oc Sci 10:29-38

Srokosz MA, Bryden HL (2015) Observing the Atlantic Meridional Overturning Circulation yields a decade of inevitable surprises. Science 348:1-5

Stommel H (1961) Thermohaline convection with two stable regimes of flow. Tellus 13(2):224-230. https://doi.org/10.1111/j.21533490.1961.tb00079.x

Sutton RT, Allen MR (1997) Decadal predictability of North Atlantic sea surface temperature and climate. Nature 388:563-567

Sutton RT, Hodson DLR (2005) Atlantic Ocean Forcing of North American and European Summer Climate. Science 309:115-118. https://science.sciencemag.org/content/309/5731/115

Vellinga M, Wood RA (2008) Impacts of thermohaline circulation shutdown in the twenty-first century. Clim Change 91:43-63. https:// doi.org/10.1007/s10584-006-9146-y

Visbeck M, Chassignet E, Curry R, Delworth TL, Dickson R, Krahmann G (2003) The ocean's response to North Atlantic Oscillation variability, in the North Atlantic Oscillation: climatic significance and environmental impact. Geophys Monogr Ser. https://doi.org/ 10.1029/134GM06

Wood RA, Keen AB, Mitchell JFB, Gregory JM (1999) Changing spatial structure of the thermohaline circulation in response to atmospheric $\mathrm{CO}_{2}$ forcing in a climate model. Nature 399:572-575

Wouters B, Drijfhout S, Hazeleger W (2012) Interdecadal North-Atlantic meridional overturning circulation variability in EC-EARTH. Clim Dyn 39:2695-2712

Wunsch C, Heimbach P (2013) Two decades of the atlantic meridional overturning circulation: anatomy, variations, extremes, prediction, an overcoming its limitations. J Clim 26:7167-7186. https://journ als.ametsoc.org/jcli/article/26/18/7167/34385/Two-Decades-ofthe-Atlantic-Meridional-Overturning

Yeager S, Danabasoglu G (2012) Sensitivity of Atlantic meridional overturning circulation variability to parameterized Nordic Sea overflows in CCSM4. J Clim 25(6):2077-2103. https://doi.org/ 10.1175/JCLI-D-11-00149.1
Yeager S, Danabasoglu G (2014) The origins of late-twentieth-century variations in the large-scale North Atlantic circulation. J Clim 27(9):3222-3247. https://journals.ametsoc.org/jcli/article/27/9/ 3222/35168/The-Origins-of-Late-Twentieth-Century-Variations

Zhang R (2010) Northward intensification of anthropogenically forced changes in the Atlantic Meridional Overturning Circulation (AMOC). Geophys Res Lett 37:L24603. https://doi.org/10.1029/ 2010GL045054

Zhang R, Delworth TL (2005) Simulated tropical response to a substantial weakening of the Atlantic thermohaline circulation. J Clim 18(12):1853-1860

Zhang R, Vallis GK (2007) The Role of Bottom Vortex Stretching on the Path of the North Atlantic Western Boundary Current and on the Northern Recirculation Gyre. J Phys Oc 37:2053-2080. https://journals.ametsoc.org/view/journals/phoc/37/8/jpo3102.1. $\mathrm{xml}$

Zhang R, Delworth TL, Rosati A, Anderson WG, Dixon KW, Lee HC et al (2011) Sensitivity of the North Atlantic Ocean Circulation to an abrupt change in the Nordic Sea overflow in a high resolution global climate model. J Geophys Res Oc. https://doi.org/10. 1029/2011JC007240

Zhang R, Sutton R, Danabasoglu G, Kwon Y-O, Marsh R, Yeager $S$ et al (2019) A review of the role of the Atlantic Meridional Overturning Circulation in Atlantic multidecadal variability and associated climate impacts. Rev Geophys 57:316-375. https://doi. org/10.1029/2019RG000644

Zhu C, Liu Z, (2020) Weakening Atlantic Overturning circulation causes South Atlantic salinity pile-up. Nat Clim Change 10:9981003. https://www.nature.com/articles/s41558-020-0897-7

Publisher's Note Springer Nature remains neutral with regard to jurisdictional claims in published maps and institutional affiliations. 